\title{
Evaluasi Hasil Preparasi Servikal pada Model Kerja Gigi Tiruan Jembatan
}

\author{
Fransiska Nuning, Poetry Oktanauli, dan Herjanti Tyawati \\ Bagian Prostodonsia Fakultas Kedokteran Gigi Universitas Prof. Dr. Moestopo (Beragama) \\ Jl. Bintaro Permai Raya No.3, Jakarta Selatan, Indonesia; e-mail: nuningphynx@gmail.com
}

\begin{abstract}
ABSTRAK
Ketepatan preparasi tepi servikal merupakan elemen terpenting dalam mengevaluasi sebuah restorasi. Restorasi yang baik didapat dari hasil pencetakan yang akurat dengan tepi servikal yang sesuai. Sebuah restorasi dapat dikatakan berhasil bertahan di dalam rongga mulut jika tepi servikal dapat beradaptasi dengan permukaan garis tepi preparasi. Penelitian dilakukan pada 57 pasien dari mahasiswa yang sedang melakukan kerja di klinik prostodonsia. Kriteria penelitian adalah tepat dan tidak tepat berdasarkan penelitian terdahulu yang mendapatkan hasil evaluasi sebanyak $70 \%$ pada model kerja. Hasil penelitian menunjukkan evaluasi preparasi servikal pada model kerja yang termasuk tepat sebanyak $78,95 \%$.
\end{abstract}

Maj Ked Gi. Juni 2014; 21(1): 9 -12.

Kata kunci: gigi tiruan jembatan, preparasi tepi servikal

ABSTRACT: Evaluation of Cervical Working Model Bridge Preparation. The accuracy of the cervical edge preparation is the most important element in evaluating a restoration. Good restoration results obtained from accurate impression with cervical corresponding side. A restoration was successful to survive in the oral cavity if it can adapt to the cervical edge surface preparation line side. The study was conducted on 57 patients of the students who are doing work in clinics Prosthodontics. Research criteria are appropriate and not appropriate based on previous research that gets results of the evaluation as much as $70 \%$ on the operating model. The results showed the assessment of cervical preparation in proper working model that included as many as $78,95 \%$.

Maj Ked Gi. Juni 2014; 21(1): 9 - 12.

Keywords: denture bridges, cervical edge preparation

\section{PENDAHULUAN}

Ketepatan preparasi tepi servikal merupakan elemen terpenting dalam mengevaluasi sebuah restorasi. Tetapi hingga saat ini tidak ada ketetapan tentang definisi secara klinis bagaimana suatu preparasi tepi servikal yang baik. Pencetakan yang baik merupakan suatu kebutuhan penting dalam pembuatan di laboratorium untuk pembuatan restorasi. Menurut Rosentiel, Land dan Fujimoto, suatu pencetakan dapat diterima walaupun ada defek kecil. ${ }^{1}$

Ketika membuat pencetakan mahkota tiruan, preparasi servikal menjadi bagian terpenting saat mengevaluasi apakah sebuah pencetakan dapat diterima atau tidak. Sebuah restorasi dapat dikatakan berhasil bertahan di dalam rongga mulut jika tepi servikal dapat beradaptasi dengan permukaan garis tepi preparasi. Saat tepi preparasi dari model kerja di duplikasi, harus ada elemen penting yang terlihat dengan jelas dari preparasi gigi untuk pembuatan pencetakan. Salah satu masalah dalam pencetakan adalah kenyataan bahwa suatu pencetakan dapat terlihat baik walaupun sudah terjadi distorsi. ${ }^{1}$

Pada pembuatan gigi tiruan jembatan selalu ada kemungkinan beberapa kesalahan kecil tentang penempatan tepi servikal gigi. Pada beberapa kasus tergantung dari derajat kemiringan suatu preparasi gigi. Agar dapat mencegah kerusakkan pada gigi tiruan jembatan logam porselen, maka harus dibuat suatu preparasi yang tepat bagi ketebalan logamnya untuk mencegah distorsi. ${ }^{2}$ Pada preparasi gigi anterior dengan akar yang tunggal perlu diperhatikan pula kesejajaran gigi penyangganya. Preparasi servikal pada gigi anterior terlihat lebih mudah karena dapat dilihat dengan mata secara langsung, tetapi kadangpula terdapat kesalahan dari operator. ${ }^{3}$ Pada preparasi gigi posterior harus diperhatikan adanya akar lebih dari satu sebagai gigi penyangga, sehingga 
preparasi juga memetingkan adanya kesejajaran dari kedua gigi penyangga. Permukaan gigi posterior juga dipreparasi lebih banyak sehingga memerlukan ketrampilan yang lebih dari operator. ${ }^{3}$

Penelitian tentang evaluasi pencetakan dan model kerja pernah dilakukan oleh Gitta Radjaeipour pada Fakultas Kedokteran Gigi Universitas Pacific Arthur di San Fransisco pada tahun 2007. Hasil yang didapat pada penelitian tersebut adalah $18 \%$ kesalahan terdapat pada preparasi servikal gigi, $8 \%$ kesalahan pada pencetakan dan $4 \%$ kesalahan pada preparasi gigi serta pencetakan. Hasil evaluasi sebanyak $70 \%$ pada model kerja dapat diterima oleh teknisi laboran untuk pembuatan protesa, sehingga pihak teknisi laboran dapat mengerjakan mahkota logam porselen jembatan secara langsung. ${ }^{1}$

Tujuan penelitian ini adalah untuk mengevaluasi berapa banyak preparasi yang dilakukan mahasiswa dapat dikerjakan secara langsung oleh teknisi laboran untuk pembuatan mahkota tiruannya, dihubungkan dengan gender serta angkatan masuk mahasiswa di FKG. Adapun tujuan penelitian lainnya untuk mengetahui apakah preparasi posterior lebih sulit dibandingkan preparasi anterior. Adapun manfaat yang didapat dari penelitian ini adalah memperkirakan berapa banyak hasil preparasi mahasiswa dapat langsung dikirim ke teknisi laboran supaya menghemat waktu dan dapat dikerjakan secara langsung tanpa perbaikan.

\section{METODE PENELITIAN}

Penelitian yang dilakukan telah mendapat persetujuan dari komisi etik Fakultas Kedokteran Gigi Universitas Prof.Dr.Moestopo (beragama). Jenis penelitian adalah cross sectional dengan melihat kemampuan mahasiswa dalam melakukan preparasi. Hasil preparasi pada model kerja dicatat beserta mahasiswa yang mengerjakan serta gender dan angkatan masuk kuliah yang pada akhirnya akan dihubungkan dengan masa studi. Hal ini nantinya akan dihubungkan apakah masa studi serta gender berpengaruh terhadap hasil preparasi servikal pada model kerja. Subyek penelitian semua pasien gigi tiruan jembatan yang bersedia datang untuk dilakukan preparasi dan pencetakan. Sebagai kriteria inklusif adalah pasien dengan kehilangan 1 gigi di regio anterior atau posterior, tidak mempunyai kelainan sistemik, serta berusia 20-50 tahun. Kriteria eksklusifnya adalah pasien dengan indikasi mahkota tiruan penuh. Jumlah sampel yang melakukan preparasi adalah 57 mahasiswa FKG UPDM (B) yang sedang melakukan praktek kerja preparasi gigi tiruan jembatan, baik pada gigi anterior dan posterior.

Sebelum melakukan preparasi pada pasien, dilakukan diskusi terlebih dahulu supaya setiap mahasiswa mempunyai pengetahuan seberapa dalam preparasi akan dilakukan. Hal ini juga dapat mengurangi faktor bias penelitian. Pengambilan jaringan struktur gigi pada bagian oklusal, cukup melakukan preparasi sedalam 1-1,5 mm. Preparasi permukaan fasial lebih dalam untuk penempatan porselen supaya menghasilkan penampilan yang lebih baik. Pada permukaan lingual dan lingoproximal, preparasi pengurangan gigi lebih sedikit karena menggunakan bahan logam. Pengurangan yang tepat akan menghasilkan penampilan yang baik. Diutamakan preparasi tepi servikal dengan bentuk shoulder dan chamfer ${ }^{2,3}$ Untuk mengurangi faktor bias dari preparasi maka dibagikan bur diamond bentuk shoulder dan chamfer. Pencetakkan hasil preparasi dilakukan dengan bahan cetak rubberbase. Material ini bersifat fleksibel tetapi tidak terjadi perubahan bentuk apabila disimpan lama. ${ }^{4,5,6}$ Dilakukan pengamatan terhadap model kerja.

Untuk mengurangi faktor bias dari pengukuran, maka yang melakukan pencetakan dan pengamatan model kerja dilakukan oleh satu orang peneliti. Sebagai hasil ukur, didapat kriteria TEPAT dan TIDAK TEPAT yang termasuk tidak tepat adalah garis tepi preparasi servikal terlalu tipis atau tajam, garis tepi preparasi servikal putus, terdapat beberapa tepi garis servikal, garis tepi servikal kasar, dan garis tepi servikal tidak tepat pada tempatnya. ${ }^{1}$ 


\section{HASIL PENELITIAN}

Penelitian dilakukan pada 57 mahasiswa yang sedang melakukan kerja pasien di klinik prostodonsia. Mahasiswa itu terdiri dari 46 perempuan dan 11 laki-laki. Evaluasi preparasi servikal dilakukan pada 31 model kerja rahang atas dan 26 model kerja rahang bawah. Dari hasil tadi terbagi lagi menjadi preparasi pada model kerja posterior rahang atas sebanyak 16 , posterior rahang bawah 25 serta preparasi pada gigi anterior 16. Hasil penelitian menunjukkan evaluasi preparasi servikal pada model kerja yang termasuk tepat sebanyak $78,95 \%$. Hasil preparasi yang terlihat pada model kerja terbagi atas preparasi gigi posterior dan anterior. Preparasi gigi posterior menghasilkan ketepatan sebanyak $78 \%$ sedangkan gigi anterior $81,25 \%$.

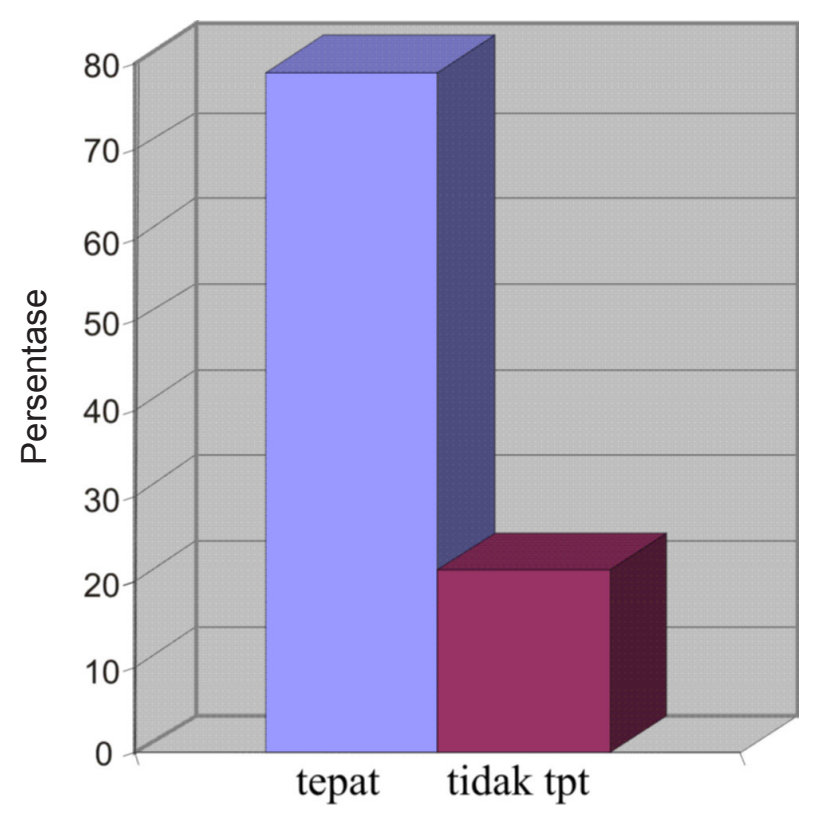

Gambar 1. Hasil evaluasi preparasi servikal pada model kerja

\section{PEMBAHASAN}

Penelitian tentang evaluasi pencetakan dan model kerja pernah dilakukan oleh Gitta Radjaeipour pada Fakultas Kedokteran Gigi Universitas Pacific Arthur di San Fransisco pada tahun $2007 .{ }^{1}$ Hasil evaluasi sebanyak $70 \%$ pada model kerja dapat diterima oleh teknisi laboran untuk pembuatan protesa. Hasil penelitian yang kami lakukan menunjukkan bahwa preparasi yang termasuk tepat sebanyak $78,95 \%$. Hal ini membuktikan bahwa hasil preparasi yang dilakukan lebih baik dari penelitian terdahulu yang hanya mendapatkan $70 \%$. Dengan kriteria hasil penelitian tersebut, mahasiswa dapat langsung mengirimkan kepada teknisi laboran untuk dilakukan pembuatan protesa jembatan logam porselen, tanpa khawatir dikembalikan karena kesalahan tepi preparasi.

Mahasiswa yang melakukan preparasi gigi tiruan jembatan sebanyak 57 mahasiswa terdiri atas 46 perempuan dan 11 laki-laki. Mahasiswa perempuan lebih banyak karena jumlah mahasiswa perempuan di FKG UGM lebih banyak dari pada laki-laki sehingga hal ini tidak dapat membuktikan kalau preparasi gigi tiruan jembatan yang dilakukan oleh perempuan lebih baik dibandingkan laki-laki. Prosedur melakukan preparasi telah diberikan pada seluruh mahasiswa melalui diskusi dengan dosen pembimbing, sehingga mahasiswa dapat melakukan preparasi servikal yang diinginkan yaitu tipe chamfer di bagian lingual/ palatal dan tipe shoulder di bagian labial/ bukal.

Mahasiswa yang bekerja di klinik prostodonsia terdiri atas beberapa angkatan, tetapi yang paling banyak bekerja pada saat penelitian ini dilakukan adalah mahasiswa yang sudah lima tahun mengecap pendidikan. Lamanya masa studi mahasiswa dalam menempuh pendidikan di FKG tidak dapat dijadikan patokan bahwa mereka tidak dapat mengerjakannya. Hal ini berdasarkan data penelitian bahwa terdapat mahasiswa dengan masa studi 10 tahun mampu menghasilkan preparasi servikal yang tepat, dibandingkan dengan beberapa mahasiswa dengan masa studi 5 tahun.

Hasil preparasi yang terlihat pada model kerja terbagi atas preparasi gigi posterior dan anterior. Preparasi gigi posterior menghasilkan ketepatan sebanyak $78 \%$ sedangkan gigi anterior $81,25 \%$. Hal ini disebabkan karena letak gigi posterior khususnya gigi molar tiga lebih jauh dari lokasi operator sehingga preparasi lebih sulit dilakukan. Gigi posterior juga mempunyai akar ganda sehingga dalam melakukan preparasi sang operator harus 
mempertimbangkan kesejajaran dari kedua akar gigi penyangga. Gigi-gigi posterior yang dilakukan evalauasipun kebanyakan dari rahang bawah. Hal ini terjadi mengingat gigi dewasa yang pertama kali tumbuh adalah molar pertama rahang bawah, sehingga banyak pasien yang sudah kehilangan gigi tersebut menjelang dewasa. Gigi anterior rahang atas yang dilakukan preparasi sebanyak 15 sedangkan rahang bawah hanya satu. Hal ini terjadi karena gigi anterior rahang atas tumbuh terlebih dahulu sehingga lebih cepat mengalami kerusakan dibandingkan bawah. Posisi gigi anterior rahang atas yang lebih menonjol dibanding rahang bawah menyebabkan gigi tersebut mudah terkena trauma ataupun karies yang dapat menyebabkan gigi tersebut lebih dulu tanggal.

\section{KESIMPULAN}

1. Preparasi servikal yang tepat akan menghasilkan model kerja yang akurat. Penelitian ini menghasilkan ketepatan preparasi servikal yang lebih baik dari penelitian sebelumnya. 2. Penelitian ini tidak membuktikan kalau gender dan lamanya menempuh pendidikan berpengaruh terhadap ketepatan preparasi servikal. 3. Letak gigi yang dilakukan preparasi berpengaruh karena gigi anterior lebih banyak yang tepat dibandingkan gigi posterior. Penelitian serupa dapat dilakukan kembali dengan jumlah sampel lebih banyak serta alat yang lebih modern.

\section{DAFTAR PUSTAKA}

1. Radjaeipour G. Improving decision-making in restorations: evaluation of impressions and working casts. Cda journal. 2007; 35(9): 637640.

2. Shillingburg H, Hobo $S$, Whitsett LD, Jacobi $\mathrm{R}$, Brackett SE. Fundamentals of fixed prosthodontics. $3^{\text {rd }}$ ed. Chicago: Quintessence Publishing Co; 1997. h.139-54, 281-308.

3. Smith BGN, Howe LC. Planning and making crowns and bridges. $3^{\text {rd }}$ ed. United Kingdom: Informa Healthcare; 2007. h. 3-100.

4. Craig RG, Powers JM, Wataha JC. Dental materials properties and manipulation. $7^{\text {th }}$ ed. St.Louis: CV. Mosby Co; h. 143-56.

5. Ralph W, Phillips MS. Elements of dental materials properties for dental hygienist and assistants. $5^{\text {th }}$ ed. Indiana: WB.Saunders Company; h. 52-53.

6. Anusavice KJ, Phillips science of dental materials. $10^{\text {th }}$ ed. Missouri: WB.Saunders Company; 1996. p. 177-83.

7. O'Brien WJ. Dental materials and their selection. $3^{\text {rd }}$ ed. Chicago: Quintessence Publishing Co, Inc; 2002. p. 90-112.

8. Rosentiel SF. Contemporary fixed prosthodontics. $1^{\text {st }}$ ed. CV. St.Louis. Toronto: London Mosby Co;.1988. p: 3-37,115-65.

9. Tylman SD, Malone WFP. Tylman's teori and practice of fixed prosthodontics. $7^{\text {th }}$ ed. St.Louis: CV.Mosby.Co; 1978. p: 57-67. 